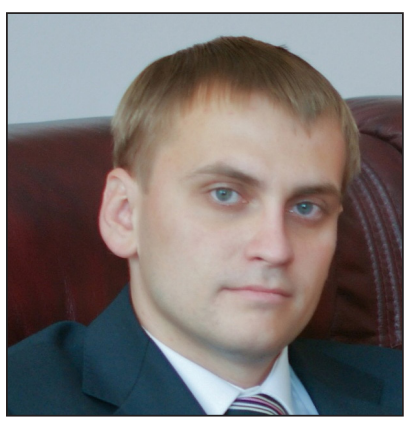

\author{
Заборовський Віктор Вікторович, \\ кандидат юридичних наук, дочент, \\ Ужгородський національний університет, \\ адвокат, \\ Україна, м. Ужгород \\ e-mail:zaborovskyviktor@rambler.ru
}

\title{
YAK 347.965.9
}

\section{АО ПИТАННЯ ПРО АЕФІНІЦІЮ ПОНЯТТЯ «ААВОКАТ»}

Стаття присвячена проблемі дефініції поняття «адвокат». Вказується на доцільність використання подвійної правової основи при формуванні дефінічії поняття «адвокат». Ставиться під сумнів доцільність існування вказаної дефініції, яка закріплена положеннями чинного законодавства про адвокатуру, та пропонується авторське визначення поняття «адвокат».

Ключові слова: адвокат; адвокатська діяльність; статус адвоката; дефініція поняття «адвокат»; функціональне призначення адвоката.

Заборовский B. В., кандидат юридических наук, доцент, Ужгородский национальный университет, адвокат, Украина, г. Ужгород.

e-mail: zaborovskyviktor@rambler.ru

К вопросу о дефиниции понятия «адвокат»

Статья посвящена проблеме дефиниции понятия «адвокат». Указывается на целесообразность использования двойной правовой основы при формировании дефиниции понятия «адвокат». Ставится под сомнение целесообразность существования указанной дефиници, которая закреплена положениями действующего законодательства об адвокатуре, и предлагается авторское определение понятия «адвокат».

Ключевые слова: адвокат; адвокатская деятельность; статус адвоката; дефиниция понятия «адвокат»; функциональное назначение адвоката.

Bcmyn. Відповідно до ст. 55 Конституції України найвищою юридичною гарантією прав і свобод людини і громадянина є їх судовий захист. Реалізація судового захисту в усіх видах провадження (конституційному, цивільному, господарському, адміністративному, кримінальному) нерозривно пов'язана з одним з основних конституційних прав людини і громадянина в Україні, а саме з правом на одержання правової допомоги. Беззаперечним залишається факт, що основними суб'єктами, на яких покладається обов'язок надання такої допомоги, є адвокати, діяльність яких розглядається як один з основних складників розбудови верховенства права в кожній країні. 
Ажтуальність теми дослідження полягає в тому, що поняття «адвокат» розглядається з різних точок зору, а отже, характеризується наявністю різних за змістом трактувань. Таке неоднозначне розуміння сутності дефініції поняття «адвокат» породжує ситуацію, за якою ускладнюється подальше дослідження питань, що пов'язані, зокрема, як зі статусом адвоката, так і здійснення ним професійної діяльності.

Аналіз останніх досліджень $і$ публікащій. Дефініція поняття «адвокат» була предметом досліджень багатьох сучасних науковців, серед яких доцільно виокремити праці В. М. Буробина, В. О. Вайпана, Є. В. Васьковського, Т. В. Варфоломєєвої, О. П. Галоганова, В. Р. Дюкіної, С. Ф. Сафулька, О. Д. Святоцького, В. І. Сергеєва, Ю. І. Стецовського, Ю. С. Шемшученка, І. С. Яртих та ін. Проте значна кількість питань у даній сфері залишаються дискусійними.

Метою cmammi є розгляд різноманітних точок зору щодо дефініції поняття «адвокат», а основним завданням - аналіз як наукових, так і законодавчо закріплених підходів щодо визначення даного поняття задля найбільш повного його розуміння, що в подальшому сприятиме належному дослідженню особливостей статусу адвоката.

Виклад основного матеріалу. Незважаючи на багатовікову практику використання поняття «адвокат», воно наразі не отримало якоїсь єдиної, так би мовити, «строгої» дефініції. Найбільш поширеною в юридичній літературі є точка зору, за якою термін «адвокат» походить від латинського слова «advocare», «advocatus» (закликати, покликаний). 3 таких позицій, зокрема, виходив Є. В. Васьковський, який зазначав, що слово «адвокат» походить від латинського кореня «advocare, advocatus» (закликати, покликаний). Він також вказував на те, що спочатку римляни позначали ім'ям «адвокат» родичів і друзів позивача, яких він просив супроводжувати його на суд. Тільки за часів імперії цей термін став застосовуватися до судових захисників [1, с. 1]. Ідентичної позиції дотримуються також О. П. Галоганов [2, с. 94], I. С. Яртих [3, с. 94] та інші науковці [4, с. 5].

На нашу думку, більш правильною є позиція тих науковців, які вказують, що термін «адвокат» походить від латинського слова «advocare» - кликати на допомогу (Ю. І. Стецовський [5, с. 2], В. І. Сергеєв [6, с. 31], В.О. Вайпан [7, с. 110]). А вже під визначенням поняття «адвокат» (від латинського слова «advocatus» - «запрошений», тобто запрошений захищати в суді, вести справу [8, с. 167]) слід розуміти, як зазначав ще в 1914 р. О. А Петрученко, «обізнану особу, як радника, захисника в суді» [9, с. 18].

У подальшому розкриття дефініції поняття «адвокат» відбувається, як правило, шляхом розкриття професійного (функціонального) призначення такої особи щодо захисту, представництва або ж в загальному - надання юридичної допомоги іншим особам. При чому, деякі науковці конкретизують особу, до якої може застосовуватися поняття «адвокат», зокрема вказуючи на те, що ним може бути лише юрист (захисник, повірений, юридичний радник тощо), інші 
використовують більш загальний підхід, наголошуючи, що адвокатом є будьяка особа, яка надає юридичну допомогу. Так, адвоката як юриста розглядають, зокрема, С. І. Ожегов і Н. Ю. Шведова (адвокат - це юрист, якому доручається надання юридичної допомоги громадянину і організації, в тому числі захист чиїх-небудь інтересів у суді) [10, с. 16] та В. О. Вайпан (під визначенням «адвокат» завжди розумівся юрист, який надає професійну правову допомогу шляхом консультацій, захисту обвинуваченого в суді і т.д.) [7, с. 110]. Особу адвоката конкретизує й С. М. Локшин, зазначаючи, що адвокат - це, по-перше, повірений у судових справах, захисник у суді, який, по-друге, усно чи письмово захищає кого-небудь, що-небудь [11, с. 16]. Розкриття поняття «адвокат» шляхом визначення кола осіб, на яких воно поширюється, міститься і в тлумачному словнику I. В. Даля, де під цим терміном розуміється присяжний повірений, правознавець, який бере на себе ведення позовів і захист підсудного; приватний посередник з позовів, стряпчий, ходок, ділок [12, с. 5].

Більш узагальнююче визначення поняття «адвокат» надається, наприклад, в енциклопедичних словниках та юридичних енциклопедіях. Так, у Великому енциклопедичному словнику за редакцією О. М. Прохорова вказується на те, що адвокат - це особа, професія якого - надання юридичної допомоги громадянам і організаціям, в тому числі й захист інтересів у суді [13, с. 19]. Подібне визначення надано і в Юридичній енциклопедії за редакцією Ю. С. Шемшученка (адвокат - це особа, яка надає фізичним і юридичним особам різні види юридичної допомоги, передбачені законодавством) [14]. В юридичній літературі зустрічаються й визначення поняття «адвокат», в яких автори узагальнюють низку професійних якостей в одній професії. Так, І. Рафальська вказує на те, що адвокат - це юридичний радник, захисник, джерело правових знань, медіатор у спорі й, дуже хотілося б, - взірець професіоналізму та професійної етики, адже тільки у даній професії є особливі етичні норми, спеціальні правила, яким адвокат має відповідати й за порушення яких він несе відповідальність [15, с. 8]. Об'єднуючим фактором вищевказаних дефініцій поняття «адвокат» є те, що в їх основі лежить професійне (функціональне) призначення такої особи.

На нашу думку, в даному випадку насамперед слід враховувати природу адвокатської діяльності, сутність якої полягає в наданні правової допомоги всім без винятку особам. При цьому не слід забувати й те, що надання такої допомоги на належному рівні може бути реалізоване лише особами, які мають відповідну кваліфікацію та відповідають певним вимогам. Тому ми поділяємо позицію тих науковців, які вважають, що «поняття «адвокат» складається з двох частин: перша визначає його правову (статусну) сторону, друга - функціональну, тобто призначення адвоката» [16, с. 121; 17, с. 16]. У цьому аспекті становить інтерес позиція В. О. Вайпан, який досліджує легально закріплене визначення поняття «адвокат» за російським законодавством: адвокат - це особа, яка отримала у встановленому законом порядку 
статус адвоката і право здійснювати адвокатську діяльність. Адвокат є незалежним професійним радником з правових питань (ч. 1 ст. 2 Федерального закону РФ «Про адвокатську діяльність та адвокатуру» [18]). 3 огляду на це він вказує, що правову (статусну) сторону даного поняття складає та частина, що стосується порядку набуття статусу адвоката), тоді як вказівка на те, що адвокат є незалежним радником з правових питань, являє собою функціональну сторону, в ім'я якої, по суті, й необхідне дотримання спеціальних вимог про набуття статусу адвоката. Враховуючи вказане, В. О. Вайпан доходить до висновку, що «тільки в єдності з законністю набуття статусу адвоката і з незалежністю адвоката як радника свого клієнта з правових питань і може розглядатися фігура сучасного адвоката» [16, с. 121].

3 подвійної правової основи визначення поняття «адвокат» (за наявності як статусної, так і функціональної сторін) виходить і законодавство ЄС. До такого висновку дозволяє дійти аналіз положення п. 1 ч. 2 ст. 1 Директиви 98/5/ЄС Свропейського Парламенту та Ради Свропейського Союзу від 16.02.1998 р. про спрощення порядку здійснення на постійній основі адвокатської професії в іншій країні-члена ніж там, де була отримана кваліфікація [19]. У даному положенні вказується на те, що поняття «адвокат» означає будь-яку особу, яка є громадянином країни-члена і хто уповноважений здійснювати професійну діяльність під професійним титулом «адвокат» (наприклад, у Великобританії - solicitor; barrister/advocate; Литві - advokatas; Німеччині - Rechtsanwalt; Польщі - adwokat; radca prawny; Румунії - avocat; Словакії - advokát/advokátka; Угорщині - ügyvéd; Франції - avocat; Чеській Республіці - advokát).

Поєднання статусної та функціональної сторін у визначенні поняття «адвокат» простежується у законодавстві фактично всіх країнах-членів ЄС. Так, у ч. 1 ст. 542 Органічного закону Іспанії «ро судову владу» від 1.07.1985 р. № 6 [10] вказується, що назва і діяльність адвоката відносяться виключно до осіб з вищою освітою в галузі права, які професійно здійснюють захист і представляють інтереси сторін у процесах будь-якого роду або надають юридичну допомогу та консультування. До такого ж висновку доходить і В. Р. Дюкіна, яка на основі аналізу національних законодавств і права Європейського Союзу пропонує таке комплексне поняття «адвокат»: «це професійний кваліфікований незалежний фахівець у галузі юриспруденції, що отримав у встановленому нормативними правовими актами країн-членів $Є С$ відповідний статус, що дозволяє йому під спеціальним професійним званням займатися консультуванням з правових питань, відстоювати права клієнтів будь-яким законним способом і здійснювати правові дії для захисту їхніх інтересів, а також представляти інтереси клієнтів перед судовими інстанціями, правоохоронними органами та органами публічного управління» [21, с. 30-31].

Проте не всі законодавці країн-членів СС використовують вищевказану подвійну правову основу при формуванні поняття «адвокат». До такого 
висновку нас підводить твердження В. М. Буробіна, який зазначає: «Необхідно відмітити те, що у Франції термін «адвокат» означає не звання, а вид професійної діяльності практикуючої особи. Тому кожна особа, яка має кваліфікацію адвоката, але котра припинила працювати в адвокатурі, навіть якщо ця особа продовжує працювати в інших сферах права, більше не може іменуватись адвокатом» [22, с. 226]. Дане твердження дозволяє дійти висновку, що французький адвокат надає перевагу функціональній стороні у формуванні поняття «адвокат».

У даному випадку потрібно звернути увагу й на те, що зовсім інший підхід характерний, наприклад, для положень Резолюції Генеральної асамблеї ООН № 46/119 від 18.02.1992 р. «Захист психічно хворих осіб і поліпшення психіатричної допомоги» [23]. Так, у п. «а» визначень Додатку «Принципи захисту психічно хворих осіб і поліпшення психіатричної допомоги» зазначається, що термін «адвокат» означає юридичного або іншого кваліфікованого представника. Тобто при формуванні поняття «адвокат» основна увага приділялася вже статусній стороні даного поняття.

Щодо легально закріплених визначень поняття «адвокат», які застосовує (застосовував) національний законодавець, то можна простежити певну його непослідовність при формуванні такого поняття. Так, у попередньому Законі України «Про адвокатуру» [24] взагалі була відсутня чітка дефініція поняття «адвокат». Лише аналіз положень ст. 2 даного Закону, яка мала назву «Адвокат», вказував на те, що законодавець використовував тільки статусну сторону правової основи при формуванні такого поняття, оскільки в цій статті ним врегульовувалися лише вимоги до особи, яка могла стати адвокатом. Дещо інший підхід використовує український законодавець при формуванні поняття «адвокат» у чинному Законі України «Про адвокатуру та адвокатську діяльність» [25], в п. 1 ч. 1 ст. 1 якого зазначається : «адвокат - фізична особа, яка здійснює адвокатську діяльність на підставах та в порядку, що передбачені цим Законом». Використання національним законодавцем бланкетних норм («на підставах та в порядку») надає можливість припустити застосування ним все ж таки подвійної правової основи при формуванні поняття «адвокат».

Висновки. Викладене вище дозволяє поставити під сумнів доцільність існування саме такої дефініції поняття «адвокат». У даному випадку ми виходимо з того, що під цим поняттям слід розуміти одиницю «логічного мислення, яка найбільш безпосередньо пов'язана зі словом. Поняття вказує на суттєві ознаки предметів і явищ об'єктивного світу» [26, с. 270]. Тобто основне призначення понять - розкриття суті та змісту того явища, яке воно виражає. На нашу думку, наявність бланкетних норм не дозволяє з'ясувати основну сутність поняття «адвокат», а отже, і не виправдовує основне призначення (необхідність існування) понять взагалі. 3 огляду на це доходимо висновку, що українському законодавцю і в подальшому потрібно використовувати сутність подвійної правової основи при формуванні поняття «адвокат», але при цьому 
слід обмежитись у використанні бланкетних і відсилочних норм. Отже, вважаємо за можливе запропонувати таку дефініцію поняття «адвокат»: це фізична особа, яка у встановленому Законом порядку набула статус адвоката, а також відповідно до нього право здійснювати адвокатську діяльність щодо захисту, представництва та надання інших видів правової допомоги клієнту.

\section{Список літератури:}

1. Васьковский Е. В. Организация адвокатуры : в 2 ч. / Е. В. Васьковский. - Санкт-Петербург : Н. К. Мартынов, 1893. - Ч. 1: Очерк всеобщей истории адвокатуры. - 621 с.

2. Галоганов А. Адвокатура как институт оказания квалифицированной юридической помощи / А. Галоганов // Право и жизнь. - 2011. - № 7-8. - С. 41-53.

3. Яртых И. С. Адвокатура и гражданское общество : монография / И. С. Яртых. -Ульяновск : Обл. типография «Печатный двор», 2007. - 335 с.

4. Святоцький О. Д. Адвокатура історія і сучасність / О. Д. Святоцький, В. В. Медведчук. Київ : Ін Юре, $1997-320$ с.

5. Стецовский Ю. И. Становление адвокатуры в России / Ю. И. Стецовский. - Москва : Волтерс Клувер, 2010. - 576 с.

6. Сергеев В. И. Адвокат и адвокатура : учеб. пособие / В. И. Сергеев. - Москва : ЮНИТИ, Закон и право, 2003. - 176 с.

7. Адвокатура в России : учебник / под ред. проф. Л. А. Демидовой, В. И. Сергеева. 3-е изд., стер. - Москва : ЗАО «Юстицинформ», 2006. - 576 с.

8. Энциклопедическій словарь Брокгауза и Ефрона : в 86 т. / Подъ редакціей профессора И. Е. Андреевскаго. - Санкт-Петербург : Семеновская Типо-Литографія (И. А. Ефрона), 1890. T. I: А - Алтай. - 480 с.

9. Петрученко О. Латинско-русский словарь / О. Петрученко. - 9-е изд., испр. - Москва : Издание тов. «В. В. Дуленов, Наследники Бр. Салаевых», 1914. - 810 с.

10. Ожегов С. И. Толковый словарь русского язика / С. И. Ожегов, Н. Ю. Шведова. 2-е изд., испр. и доп. - Москва : АЗЬ, 1995. - 928 с.

11. Локшина С. М. Краткий словарь иностранных слов / С. М. Локшина. - Москва : Сов. энцикл., 1971. - 463 с.

12. Толковый словарь живаго великорускаго языка Владиміра Даля / В. И. Даль. - 2-е изд. Москва - Санкт-Петербург : Изданіе книгопродавца-типографа М. О. Вольфа, 1880. - Т. 1: A-3. -723 c.

13. Большой энциклопедический словарь / под. ред. А. М. Прохорова. - Москва : Сов. энцикл., 1993. - 1632 с.

14. Юридична енциклопедія [Електронний ресурс] : в 6 т. / [редкол. Ю. С. Шемшученко та ін.]. - Київ : Укр. енцикл., 1998. - Т. 1: А-Г. - 672 с. - Режим доступу : http://leksika.com. ua/13870502/legal/advokat.

15. Рафальська I. Питання реформування існуючої системи адвокатури в Україні є на сьогодні нагальним, невідкладним, як невідкладним є питання реформування судової системи, системи правоохоронних органів / I. Рафальська // Юридичний журнал. - 2007. - № 11 (65). - C. 8-9.

16. Адвокатура в России : учебник / под ред. В. И. Сергеева. - 4-е изд., перераб. и доп. Москва : Юстицинформ, 2011. - 1008 с.

17. Бацвин Н. С. Статус адвоката при рассмотрении дел об административных правонарушениях / Н. С. Бацвин // Адвокатская практика. - 2009. - № 3. - С. 13-16.

18. Об адвокатской деятельности и адвокатуре Российской Федерации : Федеральный закон от 31.05.2002 г. № 63-Ф3 // Собрание законодательства РФ. - 2002. - № 23. - Ст. 2102.

19. Directive 98/5/EC of the European Parliament and of the Council of 16 February 1998 to facilitate practice of the profession of lawyer on a permanent basis in a Member State other than 
that in which the qualification was obtained [Електронний ресурс]. - Режим доступу: http://eurlex.europa.eu/legal-content/EN/TXT/PDF/?uri=CELEX:31998L0005\&from=EN.

20. Del Poder Judicial [Електронний ресурс]: Ley Orgбnica, de 1 de julio 1985 № 6/1985. Режим доступу: http://www.boe.es/buscar/act.php?id=BOE-A-1985-12666.

21. Дюкина В. Р. Гражданско-правовое регулирование оказания адвокатских услуг в праве Европейского Союза : дис. ... канд.. юрид. наук : 12.00 .03 / Вероника Раисовна Дюкина. - Москва, 2014. - $201 \mathrm{c}$.

22. Адвокатская деятельность : учеб.-практ. пособие / под общ. ред. В.Н. Буробина. -2-е изд., перераб. и доп. - Москва : «ИКФ «ЭКМОС», 2003. - 624 с.

23. Захист психічно хворих осіб і поліпшення психіатричної допомоги [Електронний ресурс] : Резолюція Генеральної асамблеї ООН від 18.02.1992 р. № 46/119. - Режим доступу : http://zakon4.rada.gov.ua/laws/show/995_905.

24. Про адвокатуру: Закон України від 19.12.1992 р. № 2887-ХІІ (втратив чинність) // Відом. Верхов. Ради України. - 1993. - № 9. - Ст. 62.

25. Про адвокатуру та адвокатську діяльність : Закон України від 05.07.2012 р. № 5076-VI // Офіційний вісник України. - 2012. - № 62. - Ст. 17.

26. Жеребило Т. В. Словарь лингвистических терминов / Т. В. Жеребило. - 5-е изд., испр. и доп. - Назрань : ООО «Пилигрим», 2010. - 486 с.

\section{References:}

1. Vaskovskiy, E. V. Organizatsiya advokaturyi: v 2 ch. / E. V. Vaskovskiy. S.-Pb. : N. K. Martyinov, 1893. Ch. 1 : Ocherk vseobschey istorii advokaturyi. 621 s. [in Russian].

2. Galoganov, A. Advokatura kak institut okazaniya kvalifitsirovannoy yuridicheskoy pomoschi / A. Galoganov // Pravo i zhizn. 2011. N 7-8. S. 41-53. [in Russian].

3. Yartyih, I. S. Advokatura i grazhdanskoe obschestvo : monografiya / I. S. Yartyih. Ulyanovsk: Oblastnaya tipografiya «Pechatnyiy dvor», 2007. 335 s. [in Russian].

4. Svyatotskiy, O. D. Advokatura istoriya i suchasnist / O. D. Svyatotskiy, V.V. Medvedchuk. Kiyv: In. Yure, 1997320 s. [in Ukrainian]

5. Stetsovskiy, Yu. I. Stanovlenie advokaturyi v Rossii / Yu. I. Stetsovskiy. Moskow : Volters Kluver, 2010. 576 s. [in Russian].

6. Sergeev, V. I. Advokat i advokatura : ucheb. posobie / V. I. Sergeev. Moskow : YuNITI, Zakon i pravo, 2003. 176 s. [in Russian].

7. Advokatura v Rossii : uchebnik / Pod red. prof. L. A. Demidovoy, V. I. Sergeeva. 3-e izd., ster. Moskow : ZAO Yustitsinform, 2006. 576 s. [in Russian].

8. Entsiklopedicheskiy slovar Brokgauza i Efrona : v 86 tomah / Pod' redaktsiey professora I. E. Andreevskago. SPb.: Semenovskaya Tipo-LitografIya (I. A. Efrona), 1890. Tom' I. A-Altay. 480 s. [in Russian].

9. Petruchenko, O. Latinsko-russkiy slovar / O. Petruchenko. 9-e izd., ispr. Moskow : Izdanie tovarischestva «V.V. Dulenov, Nasledniki Br. Salaevyih», 1914. 810 s. [in Russian].

10. Ozhegov, S.I. Tolkovyiy slovar russkogo yazika / S.I. Ozhegov, N.Yu. Shvedova. 2-e uzd., ispr. i dop. Moskow : Izd. AZъ, 1995. 928 s. [in Russian].

11. Lokshina, S. M. Kratkiy slovar inostrannyih slov / S. M. Lokshina. M.: Sovetskaya Entsiklopediya, 1971. 463 s. [in Russian].

12. Tolkovyiy slovar zhivago velikoruskago yazyika VladimIra Dalya / V.I. Dal. 2-e izd. M.-SPb.: Izdanie knigoprodavtsa-tipografa M.O. Volfa, 1880. T. 1. A-Z. 723 s. [in Russian].

13. Bolshoy entsiklopedicheskiy slovar / Pod. red. A. M. Prohorova. Moskow : Sovetskaya entsiklopediya, 1993. $1632 \mathrm{~s}$. [in Russian].

14. Yuridichna entsiklopediya [Elektronniy resurs]: v 6 t. / [redkol. Yu.S. Shemshuchenko ta in.]. Kyiv : Ukr.entsikl., 1998. T. 1: A-G 672 s. Rezhim dostupu: http://leksika.com.ua/13870502/legal/ advokat. [in Ukrainian]. 
15. Rafalska, I. Pitannya reformuvannya isnuyuchoyi sistemi advokaturi v Ukrayini e na sogodni nagalnim, nevidkladnim, yak nevidkladnim e pitannya reformuvannya sudovoyi sistemi, sistemi pravoohoronnih organiv / I. Rafalska // Yuridichniy zhurnal. 2007. N 11 (65). S. 8-9. [in Ukrainian]

16. Advokatura v Rossii : uchebnik / Pod red. V.I.Sergeeva. 4-e izd., pererab. i dop. Moskow : Yustitsinform, 2011. 1008 s. [in Russian].

17. Batsvin, N. S. Status advokata pri rassmotrenii del ob administrativnyih pravonarusheniyah / N. S. Batsvin // Advokatskaya praktika. 2009. N 3. S. 13-16. [in Russian].

18. Ob advokatskoy deyatelnosti i advokature Rossiyskoy Federatsii : Federalnyiy zakon ot 31 maya 2002 g. № 63-FZ // Sobranie zakonodatelstva RF. 2002. N 23. St. 2102. [in Russian].

19. Directive 98/5/EC of the European Parliament and of the Council of 16 February 1998 to facilitate practice of the profession of lawyer on a permanent basis in a Member State other than that in which the qualification was obtained [Elektronniy resurs]. Rezhim dostupu: http://eur-lex. europa.eu/legal content/EN/TXT/PDF/?uri=CELEX:31998L0005\&from=EN.

20. Del Poder Judicial [Elektronniy resurs]: Ley Orgбnica, de 1 de julio 1985 № 6/1985. Rezhim dostupu: http://www.boe.es/buscar/act.php?id=BOE-A-1985-12666.

21. Dyukina, V. R. Grazhdansko-pravovoe regulirovanie okazaniya advokatskih uslug v prave Evropeyskogo Soyuza: dis. ... kandidata yurid. nauk : 12.00 .03 / Dyukina Veronika Raisovna. Moskow, 2014. 201 s. [in Russian].

22. Advokatskaya deyatelnost: uchebno-prakticheskoe posobie / Pod obsch. red. V.N. Burobina. 2-e izd., pererab. i dopol. Moskow «IKF «EKMOS», 2003. 624 s. [in Russian].

23. Zahist psihichno hvorih osib i polipshennya psihiatrichnoyi dopomogi [Elektronniy resurs] : Rezolyutsiya Generalnoyi asambleyi OON vid 18 lyutogo 1992 roku N 46/119. Rezhim dostupu: http://zakon4.rada.gov.ua/laws/show/995_905. [in Ukrainian].

24. Pro advokaturu: Zakon Ukrayini vid 19 grudnya 1992 roku № 2887-XII (vtrativ chinnist) // Vidomosti Verhovnoi Radi Ukrayini. 1993. N 9. St. 62. [in Ukrainian].

25. Pro advokaturu ta advokatsku diyalnist : Zakon Ukrayini vid 5 lipnya 2012 r. № 5076-VI // Ofitsiyniy visnik Ukrayini. 2012. N 62. St. 17. [in Ukrainian].

26. Zherebilo, T. V. Slovar lingvisticheskih terminov / T.V. Zherebilo. 5-e izd., ispr. i dop. Nazran : OOO «Piligrim», 2010. 486 s. [in Russian].

Zaborovsky $\boldsymbol{V}$. V., Candidate of Legal Sciences, Associate Professor, Uzhgorod National University, advocate, Ukraine, Uzhgorod.

e-mail: zaborovskyviktor@rambler.ru

To the question of the definition of «lawyer»

The article is devoted to the problem with the definition of the concept of «lawyer». The aim is to identify the most complete understanding of the definition of the concept of «lawyer», which will continue to contribute to the proper study of the features status of the lawyer. The author used the formal-legal method on the basis of systematic and integrated its holding. The article makes a critical analysis of both scientific and legislatively fixed (including the European Union) approaches to the definition of «lazyer».

The conclusion is that the most common in the legal literature is a point of view that the disclosure of the definition of the concept of «laweyer» is done by the disclosure of professional (functional) the appointment of such a person for protection, representation, or in general - to provide legal assistance to other parties. Specify on the feasibility of using a dual legal basis for the formation of the definition of the concept of «lawyer», according to which it consists of two parts, namely, the status and the functional side. The article questioned the feasibility of the existence of this definition, the fixed provisions of the legislation on the legal profession, and offers the author's definition of the term «lawyer» - a natural person who, in the manner prescribed by law has received status of the lawyer, and the right, in accordance with this status, to carry out lawyer for the protection, representation and provision of other types of legal assistance to the client.

Keywords: lawyer; lawyer activity; lawyer's status; definition of the concept of «lawyer»; the functionality of a lawyer.

Надійшла до редколегії 14.03.2016 р. 